\title{
Species diversity of seagrass-associated bivalves as an ecological parameter to support seagrass conservation along with the Coastal Waters of South Lombok, Indonesia
}

\author{
ABDUL SYUKUR ${ }^{1,2, \nu}$, LALU ZULKIFLII ${ }^{1,2}$, AGIL AL IDRUS ${ }^{1,2}$, BAIQ NUNUNG HIDAYATI ${ }^{2}$ \\ ${ }^{1}$ Department of Biological Sciences Education, Faculty of Teacher Training and Education, Universitas Mataram. Jl. Pemuda, Selaparang, Mataram \\ 83125, West Nusa Tenggara, Indonesia. Tel. +62-370-633007, •email: syukur_unram@ymail.com \\ ${ }^{2}$ Department of Sciences Education, Graduate Program, Universitas Mataram. J1. Pendidikan No. 37, Mataram 83125, West Nusa Tenggara, Indonesia
}

Manuscript received: 22 August 2021. Revision accepted: 28 October 2021.

\begin{abstract}
Syukur A, Zulkifli L, Idrus AA, Hidayati BN. 2021. Species diversity of seagrass-associated bivalves as an ecological parameter to support seagrass conservation along with the Coastal Waters of South Lombok, Indonesia. Biodiversitas 22: 5133-5144. Seagrass has a role in supporting the survival of marine life, such as bivalves. This study aimed to investigate the relationship between bivalve species diversity as a parameter for seagrass conservation. The research approach was through observation and data collection for seagrass and bivalves using quadrant and transect methods - Analysis of the data through descriptive statistical analysis, ANOVA, and Pearson correlation. The number of seagrass species in the six research sites was nine. Furthermore, the species composition of bivalves consisted of 11 families comprising 47 species. The ANOVA results showed a significant difference based on the F-count value, higher than the F-table value of the three ecological indices ( $\mathrm{H}^{\prime}, \mathrm{E}$, and $\mathrm{Ki}$ ). Two ecological indices, namely $\mathrm{H}^{\prime}$ and $\mathrm{Ki}$, have $\mathrm{r}$ values less than 0.5 for all environmental parameters (temperature, brightness, $\mathrm{pH}$, salinity, DO, phosphate, and nitrate) and show no significant correlation. However, the $\mathrm{E}$ index value has an $\mathrm{r}$ value greater than 0.5 for nitrate, salinity DO, and phosphate. The highest significance value of the four environmental variables is for nitrate, with an $r=0.875$. The conclusion is that the richness and abundance of seagrass-associated bivalves in the study area are predetermined by the characteristics of the seagrass environment, especially the substrate. Secondly, seagrasses could create a suitable substrate for bivalves to survive. Therefore, the indicator of the presence of associated Bivalvia species can be a parameter for local scale seagrass conservation at the study site.
\end{abstract}

Keywords: Bivalvia, conservation, ecology, seagrass

\section{INTRODUCTION}

Bivalves are a group of marine organisms associated with seagrass and have a role in tropical systems in seagrass ecosystems, such as forming food chains (Sousa et al. 2009). In addition, several species of bivalves are a source of protein for public consumption, and their skins can be a source of raw material for handicraft products that have economic value (Deutsch et al. 2011; Santhanam 2018). Bivalve animal communities generally live in marine waters, especially in intertidal conditions, such as seagrass meadows (Hosack et al. 2006; Bateman and Bishop 2017). Seagrass substrate conditions are a habitat preference for distribution and species composition of benthic animals such as seashells (Best and Kidwell 2016) Therefore, the substrate can significantly affect the number of Bivalves population and even eliminate some bivalves species (Chadwick et al. 2006). Furthermore, the statement (de Souza et al. 2018) that the ecosystem's physical, chemical, and biological environment, such as damage to seagrass ecosystems, can affect the survival rate of marine biota associated with seagrass.

The relationship between seagrass and bivalves is through chemosymbiotic associations. Several bivalves support primary species (seagrass) and play a role in increasing anthropogenic impact and global climate change
(Chin et al. 2020). Seagrass has a significant meaning for bivalves' diversity, especially seagrass services in providing a habitat (Lebreton et al. 2012; Nordlund and Gullström 2013). Although the service capacity provided by seagrass may vary by seagrass species and between seagrass ecosystems (Nordlund et al. 2016), seagrassvegetated areas have contributed to the bivalve community, especially in increasing the abundance, richness, and diversity of bivalve species (Gagnon et al. 2020). In addition, environmental conditions in the seagrass area are a factor that plays a role in increasing the diversity and species richness of bivalves (Lu et al. 2018; Lukwambe et al. 2020). For example, seagrass substrates can determine whether the density of Bivalvia species is high or low (Altamirano et al. 2017).

Meanwhile, as Lee et al. (2016) state, dissolved organic matter in sediments is affected by the dense growth of organisms such as bivalves. The finer the substrate texture, the greater is its ability to trap organic matter (Duniway et al. 2010). Furthermore, Seagrasses provide a diversity of habitats for bivalve communities. However, the ecological evidence of the presence of bivalve communities in seagrass beds does not constitute the main parameter in the conservation of coastal ecosystems. Significantly, the bivalve community in seagrass is the prey of a diversity of seabirds (Unsworth and Butterworth 2021). 
The development of seagrass conservation parameters is essential at the study site, especially for protecting marine biodiversity such as bivalved communities. Previous studies have explained that the association of fish with seagrass and their use through ecotourism could indicate seagrass conservation at local and regional scales (Syukur et al. 2021a). In addition, seagrass cover is a parameter that has a significant correlation in determining the species richness of bivalves at the micro-scale (Syukur et al. 2021b). However, a broader study of the ecological aspects of the Bivalvia community on a spatial and temporal scale, especially in the study area, has not been carried out. The existing condition of the Bivalvia community at the study site can be the main parameter in the design of seagrass conservation. Therefore, the study of the ecological aspects of bivalves by seagrass habitat diversity, particularly in the study area, is critical as a parameter for seagrass environmental protection. This study aims to describe the variety of bivalve species associated with seagrass in the coastal waters of South Lombok. This research can provide scientific information on seagrass's contribution to preserving marine life, especially the bivalve community. In addition, the results of this research can be a scientific basis for the conservation of seagrass on a local scale, such as in the study area and other relevant locations.

\section{MATERIALS AND METHODS}

\section{Research sites}

The research was carried out from 2019 to 2021, and the sampling was from March to July/year. The study sites were in six areas of seagrass beds along the southern coast of Lombok Island, West Nusa Tenggara, Indonesia (Figure 1, Table 1). The research location, especially the seagrass area and its environment, is designated as a traditional fishing and coastal nature tourism area (Syukur et al. 2020). The environmental characteristics between the research locations are in Lungkak, Poton Bakau, and Awang, directly adjacent to the mangrove ecosystem. Furthermore, Gerupuk and Kute are not directly adjacent to the mangrove ecosystem. However, Gili Kere is a small island in the southern coastal waters of East Lombok. Mangrove vegetation, especially on the south coast of East Lombok, was the result of revegetation in the early 1990s (Idrus et al. 2021). The two indicators of success are the first value of fauna diversity, such as Bivalvia species associated with mangroves, both local communities have their livelihoods from the mangrove area of revegetation (Idrus et al. 2019). Therefore, the success of mangrove revegetation and its protection by local communities can be the basis for the development of seagrass protection in the study location.

\section{Data Collection and Analysis}

The data collection design of the study involved determination of intersecting points at each research station (i.e., Gili Kere, Lungkak, Poton Bakau, Awang, Gerupuk, and Kuta). The condition of seagrass beds at each study site became the basis for determining the transect length. The size and number of transects at each study site are detailed in Table 2; data collection was done using the quadrant method (Ellenberg and Mueller-Dombois and 1974).

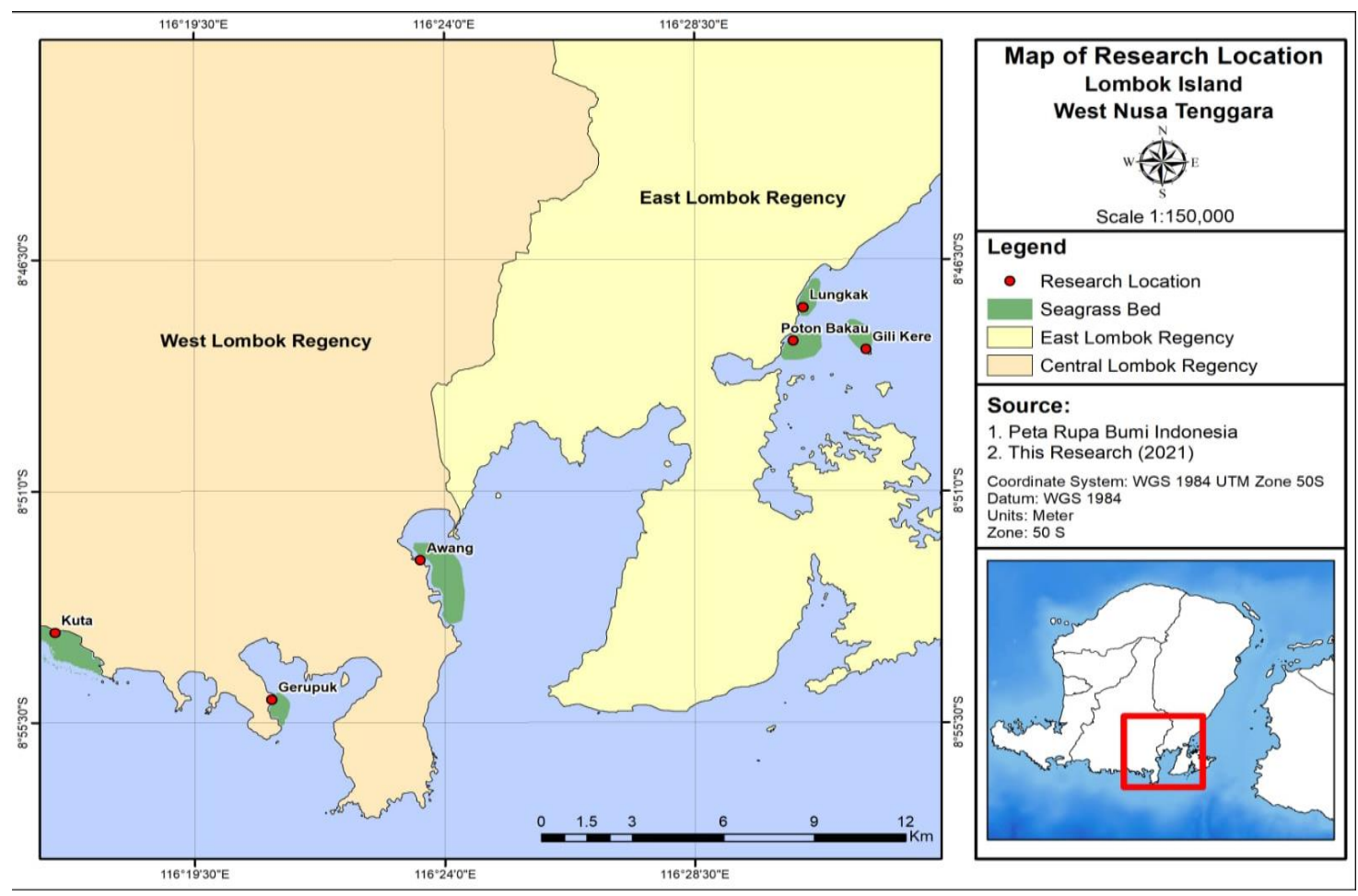

Figure 1. Map of research locations in coastal Lombok, West Nusa Tenggara, Indonesia 
Table 1. Six research sites and their coordinates

\begin{tabular}{llll}
\hline Location & X coordinate & Y coordinate & District \\
\hline Gili Kere & $116^{\circ} 31$ '35,540 "E & $8^{\circ} 48^{\prime} 14,544$ "S & East Lombok District \\
Lungkak & $116^{\circ} 30^{\prime} 27,092$ "E & $8^{\circ} 47^{\prime} 25,972$ "S & East Lombok District \\
Poton Bakau & $116^{\circ} 30^{\prime} 16,614$ "E & $8^{\circ} 48$ '5,261 "S & East Lombok District \\
Awang & $116^{\circ} 23^{\prime} 34^{\prime} \mathrm{E}$ & $8^{\circ} 52^{\prime} 21^{\prime} \mathrm{S}$ & Central Lombok District \\
Gerupuk & $116^{\circ} 20^{\prime} 53^{\prime \prime} \mathrm{E}$ & $8^{\circ} 55^{\prime}, 03$ 'S & Central Lombok District \\
Pantai Kuta & $116^{\circ} 16^{\prime} 59^{\prime} \mathrm{E}$ & $8^{\circ} 53^{\prime} 45^{\prime} \mathrm{S}$ & Central Lombok District \\
\hline
\end{tabular}

Table 2. The number and length of transects at the six research sites

\begin{tabular}{llcc}
\hline Location & EcosystemNumber of transects & $\begin{array}{c}\text { Transect length of } \\
\text { sampling at six } \\
\text { research sites }\end{array}$ \\
\hline Gili Kere & Seagrass & 9 & $1300 \mathrm{~m}$ \\
Lungkak & Seagrass & 9 & $750 \mathrm{~m}$ \\
Poton Bakau & Seagrass & 9 & $1300 \mathrm{~m}$ \\
Awang & Seagrass & 9 & $900 \mathrm{~m}$ \\
Gerupuk & Seagrass & 9 & $800 \mathrm{~m}$ \\
Kuta & Seagrass & 9 & $1200 \mathrm{~m}$ \\
\hline
\end{tabular}

Furthermore, the placement of transects was perpendicular to the coastline to the sea, and observation and research data collection happened during every full moon for three days from March to July in 2020 and 2021. Observations on research variables (seagrass and bivalves) were carried out in quadrants measuring $1 \times 1 \mathrm{~m} 2$, and the distance between the squares on each transect was $25 \mathrm{~m}$. The research variables pertained to the seagrass species, including the number of species, individual seagrasses/species, and the percentage of seagrass cover based on (Pitcher et al. 2007).

The Bivalvia variables that became the object of the research were the species and the number of individuals/species, and samples embedded in the substrate were taken by digging the substrate to a depth of $10 \mathrm{~cm}$. Then, samples were collected in prepared containers (plastic buckets) and documented through photographs for identification purposes, as guided by (Abbott 1985). Meanwhile, the environmental parameters used as research variables were the characteristics of the substrate, temperature, $\mathrm{pH}$, salinity, $\mathrm{DO}$, brightness, nitrate, and phosphate. The next stage was assessing the nitrate and phosphate content of the samples in the chemistry laboratory of the Chemistry Study Program, Faculty of Mathematics and Natural Sciences, University of Mataram. After that, other parameters (i.e., substrate characteristics, salinity, DO, brightness, $\mathrm{pH}$, and temperature) were assessed directly.

The data analysis approach employed was descriptive statistical analysis. Data analysis on the ecological index referenced several studies, including abundance analysis, which utilizes the formula from Odum (1998), density analysis, and seagrass cover using Odum's (1993) procedure. Furthermore, the Pearson correlation formula was applied using SPSS 17 and the Microsoft Excel 2007 software to determine the relationship between environmental parameters and ecological indicators (Diversity, Evenness, and Abundance).

\section{RESULTS AND DISCUSSION}

\section{Seagrass composition in the six study site}

The species richness in each research location showed a different number of species and ranged from seven to nine species. The largest seagrass species were in Lungkak, Gerupuk, and Kuta, and the lowest number was in Gili Kere (Table 3 ). The average $\%$ value of seagrass cover at the six study sites ranged from $69.5 \pm 0.7$ to $82.16 \pm 2.3$, with the highest average $\%$ of seagrass cover being at Lungak and the lowest at Gili Kere and Awang. Meanwhile, the number of seagrass species, especially in Gerupuk and Kute, is lower than in Kiswara's study (1994). Still, in Poton Bakau, it is higher than revealed by the research results of Rahman et al. (2018). The number of species is different from the data of previous studies, firstly due to differences in observation points. Secondly, there is no permanent station for monitoring the condition of seagrass and its environment regularly. However, the representation of the composition of seagrass species can explain the status of the seagrass community in the study location as a mixed type of seagrass community. Patty (2013) demonstrated that seagrass communities with more than one class and eight species are a mixed-type category. Liu et al. (2017) explained that diverse types dominated seagrass communities in Indonesian coastal waters. Furthermore, differences in seagrass species richness between seagrass meadow locations influence environmental conditions, such as substrate, salinity, and their geographic location in coastal waters (Wainwright et al. 2018).

Meanwhile, the growth, productivity, and distribution of seagrass species are more a result of the availability of light. The brightness values at all research sites are within the tolerance limits of the Seawater Quality Standard (KMNLH No. 51 of 2014). The complete results of the measurement of environmental variables at all locations of seagrass beds during the study period are in Table 4 . The values of environmental parameters, such as temperature, salinity, and dissolved oxygen (DO), are acceptable for seagrass species to survive. However, the average values of phosphate and nitrate are above the standard values of the Seawater Quality Standard, with Phosphate $(\mathrm{PO} 4-\mathrm{P})=$ 0.015 and Nitrate $(\mathrm{NO}-\mathrm{N})=0.008$ (KMNLH No. 51 of 2014). The range of phosphate values is between $0.55 \mathrm{mg} / \mathrm{l}$ - $1.10 \mathrm{mg} / \mathrm{l}$, with the highest being in Lungkak and the lowest in Gili Kere. 
Table 3. The number of species and \% of seagrass cover at each location of seagrass beds at six research sites

\begin{tabular}{|c|c|c|c|c|}
\hline Lokasi & Name of Seagrass Species & 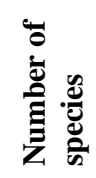 & 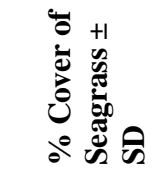 & Substrate \\
\hline Gili Kere & $\begin{array}{l}\text { Cymodocea rotundata Ascherson \& Schweinfurth in Ascherson, } 1870 \\
\text { Cymodocea serrulata (R. Brown) Ascherson \& Magnus in Ascherson, } 1870 \\
\text { Enhalus acoroides (Linnaeus f.) Royle, } 1839 \\
\text { Halodule pinifolia (Miki) Den Hartog, } 1964 \\
\text { Halophila ovalis (Robert Brown) Hook f. } 1858 \\
\text { Syringodium isoetifolium (Ascherson) Dandy, } 1939 \\
\text { Thalassia hemprichii (Ehrenberg) Ascherson, } 1871\end{array}$ & 7 & $75.33 \pm 9.0$ & $\begin{array}{l}\text { Dominant sand } \\
\text { from coral } \\
\text { fragments and a } \\
\text { little mud }\end{array}$ \\
\hline Lungkak & $\begin{array}{l}\text { Cymodocea rotundata Ascherson \& Schweinfurth in Ascherson, } 1870 \\
\text { Cymodocea serrulata (R. Brown) Ascherson \& Magnus in Ascherson, } 1870 \\
\text { Enhalus acoroides (Linnaeus f.) Royle, } 1839 \\
\text { Halodule pinifolia (Miki) Den Hartog, } 1964 \\
\text { Halodule uninervis (Forsskal) Ascherson in Boissier, } 1882 \\
\text { Halophila ovalis (Robert Brown) Hook f. } 1858 \\
\text { Halophila spinulosa (R. Brown) Ascherson, } 1875 \\
\text { Syringodium isoetifolium (Ascherson) Dandy, } 1939 \\
\text { Thalassia hemprichii (Ehrenberg) Ascherson, } 1871\end{array}$ & 9 & $82.16 \pm 2.3$ & Sandy mud \\
\hline Poton Bakau & $\begin{array}{l}\text { Cymodocea rotundata Ascherson \& Schweinfurth in Ascherson, } 1870 \\
\text { Cymodocea serrulata (R. Brown) Ascherson \& Magnus in Ascherson, } 1870 \\
\text { Enhalus acoroides (Linnaeus f.) Royle, } 1839 \\
\text { Halodule pinifolia (Miki) Den Hartog, } 1964 \\
\text { Halodule uninervis (Forsskal) Ascherson in Boissier, } 1882 \\
\text { Halophila ovalis (Robert Brown) Hook f. } 1858 \\
\text { Syringodium isoetifolium (Ascherson) Dandy, } 1939 \\
\text { Thalassia hemprichii (Ehrenberg) Ascherson, } 1871\end{array}$ & 8 & $79.5 \pm 3.0$ & Sandy mud \\
\hline Awang & $\begin{array}{l}\text { Cymodocea rotundata Ascherson \& Schweinfurth in Ascherson, } 1870 \\
\text { Cymodocea serrulata (R. Brown) Ascherson \& Magnus in Ascherson, } 1870 \\
\text { Enhalus acoroides (Linnaeus f.) Royle, } 1839 \\
\text { Halodule pinifolia (Miki) Den Hartog, } 1964 \\
\text { Halodule uninervis (Forsskal) Ascherson in Boissier, } 1882 \\
\text { Halophila ovalis (Robert Brown) Hook f. } 1858 \\
\text { Syringodium Isoetifolium (Ascherson) Dandy, } 1939\end{array}$ & 7 & $69.5 \pm 0.7$ & Sandy mud \\
\hline Gerupuk & $\begin{array}{l}\text { Cymodocea rotundata Ascherson \& Schweinfurth in Ascherson, } 1870 \\
\text { Cymodocea serrulata (R. Brown) Ascherson \& Magnus in Ascherson, } 1870 \\
\text { Enhalus acoroides (Linnaeus f.) Royle, } 1839 \\
\text { Halodule pinifolia (Miki) Den Hartog, } 1964 \\
\text { Halodule uninervis (Forsskal) Ascherson in Boissier, } 1882 \\
\text { Halophila minor (Zollinger) Den Hartog, } 1957 \\
\text { Halophila ovalis (Robert Brown) Hook f. } 1858 \\
\text { Syringodium isoetifolium (Ascherson) Dandy, } 1939 \\
\text { Thalassia hemprichii (Ehrenberg) Ascherson, } 1871\end{array}$ & 9 & $77.5 \pm 2.8$ & Muddy sand \\
\hline Kuta & $\begin{array}{l}\text { Cymodocea rotundata Ascherson \& Schweinfurth in Ascherson, } 1870 \\
\text { Cymodocea serrulata (R. Brown) Ascherson \& Magnus in Ascherson, } 1870 \\
\text { Enhalus acoroides (Linnaeus f.) Royle, } 1839 \\
\text { Halodule uninervis (Forsskal) Ascherson in Boissier, } 1882 \\
\text { Halodule pinifolia (Miki) Den Hartog, } 1964 \\
\text { Halophila ovalis (Robert Brown) Hook f. } 1858 \\
\text { Halophila minor (Zollinger) den Hartog, } 1957 \\
\text { Syringodium Isoetifolium (Ascherson) Dandy, } 1939 \\
\text { Thalassia hemprichii (Ehrenberg) Ascherson, } 1871\end{array}$ & 9 & 8.6 & Muddy sand \\
\hline
\end{tabular}

The range of nitrate values is between $0.30 \mathrm{mg} / \mathrm{l}-0.72$ $\mathrm{mg} / \mathrm{l}$, with the highest in Poton Bakau and the lowest in Gili Kere. The average weight of high phosphate content, such as in Poton Bakau, Lungkak, was sourced from rivers and run-off at the two seagrass meadows, and similarly in Awang, Gerupuk, and Kute. However, the average value of phosphate content in Gili Kere being the lowest is due to Pulau Kecil, which cannot supply from the river and run- off from the mainland of Lombok Island. In addition, it can be due to anthropogenic activities, such as waste from tourism activities, households, and traditional markets such as Kute, Gerupuk, and Lungkak, which have become tourist destinations, and from Awang, which has fishing ports and traditional markets. However, the value of the parameter ratio of nitrate and phosphate is lower than the Redfield ratio of N:P (16:1). Therefore, the overall average 
value of environmental parameters is still suitable for marine life. Moreover, seagrass is one species that can recover from disturbances originating from natural processes and anthropogenic activities (Boudouresque et al. 2009).

\section{Composition of the bivalves species found at study sites}

The six study sites' breeding species associated with seagrass totaled 44, comprising 11 families (Table 5). Species composition based on family showed that Family Veneroidae had the most species and reached $52.17 \%$ of the total bivalve species at six research sites. The next largest family is Mactridae at $8.70 \%$, and the species composition is in line with family size at all study sites (Figure 2). In addition, the species composition of bivalves based on the number of individuals is the first species with the number of individuals on the average of the total number of individuals. The average number of individuals for all 46 species was 73.67. The number of individuals was above the average for ten species, or $21.73 \%$ of the total bivalve species, at the six study sites. The composition of species with the above-average number of individuals was as follows: Anadara antiquate 19.95\%, Perna viridis $16.73 \%$, Gafrarium tumidum $9.21 \%$, Anadara granosa $8.59 \%$, Gafrarium pectinatum $7.17 \%$, Lioconcha fastigiata $3.51 \%$, Mactra nitida 3.1\%, Samela jecunda $3.07 \%$, Tapes literatus $3.07 \%$, and Tapes sulcaris $2.51 \%$ (Figure 3). Second, for 36 species or $78.26 \%$ of the total, individuals were below the average value.

The composition of bivalve species associated with seagrass at the six research sites can explain: (1) bivalve species richness, (2) both species distribution based on family and individual abundance based on species, and (3) species abundance based on the largest family and species with the most numbers of individuals. In addition, the presence of all species of Bivalvia associated with seagrass at the six research sites is evidence of the ecological services of seagrass for the survival of Bivalvia species diversity. Concerning the presence of bivalve fauna in seagrass beds, the factor that supports their survival is the complexity of seagrass habitats, which can determine the distribution and habitat preferences of fauna, including bivalve species (van der Heide et al. 2012).

Another explanation states that biodiversity in seagrass communities can facilitate the presence of bivalves and that bivalves facilitate fouling and algae diversity (Zhang and Silliman 2019). Bivalve species also show a significant correlation with the biomass of Enhalus acoroides (Satumanatpan et al. 2011). However, generally at high seagrass biomass, the number of Bivalvia species may be lower due to dense seagrass roots (van Houte-Howes et al. 2004). Although this study has not described the presence of Bivalvia species, it is relevant in producing extreme biodiversity, with evidence that Bivalvia species richness can be a parameter to support conservation and restoration programs for seagrass along the southern coast of Lombok Island.

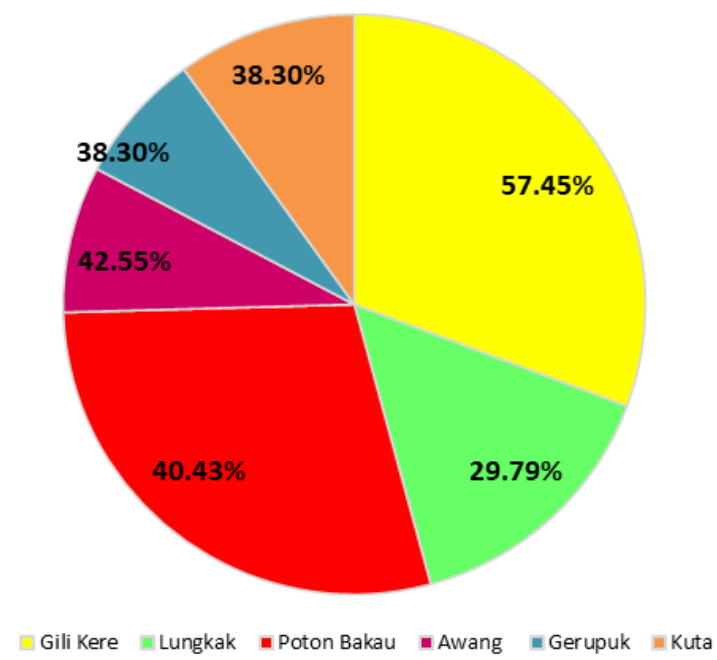

Figure 3. the percentage of all seagrass-associated bivalves species identified in this study found at each of six locations

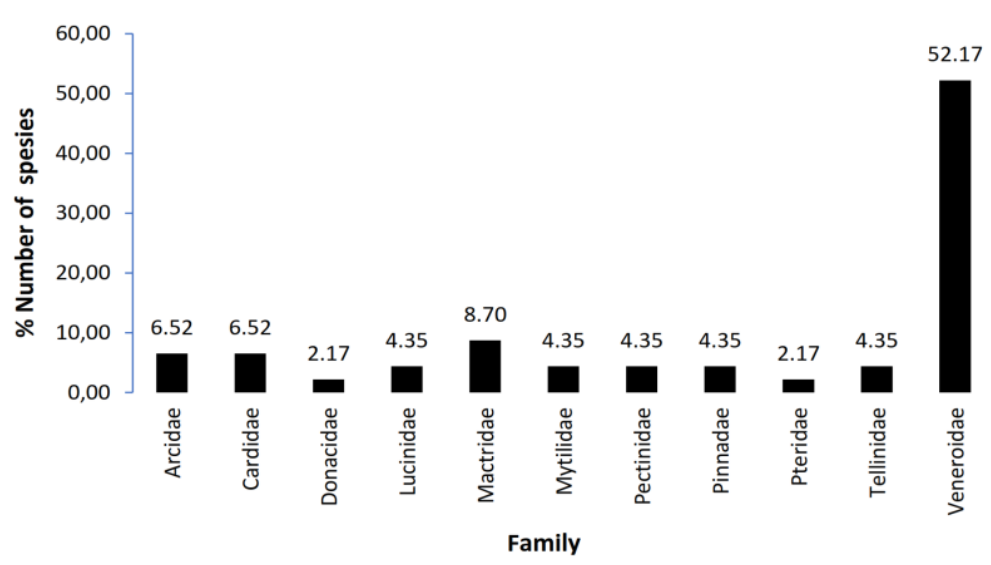

Figure 2. Species Bivalvia community composition by family based on the number of species present in the six study site 
Table 4. Measurement results of environmental parameters at six locations of seagrass beds in the study site

\begin{tabular}{|c|c|c|c|c|c|c|c|c|c|c|c|c|c|c|c|}
\hline \multirow{3}{*}{$\begin{array}{l}\text { Parameters } \\
\text { physics }\end{array}$} & \multicolumn{15}{|c|}{ Locations } \\
\hline & \multicolumn{5}{|c|}{ Gili Kere } & \multicolumn{5}{|c|}{ Lungkak } & \multicolumn{5}{|c|}{ Poton Bakau } \\
\hline & I & II & III & Average & SD & I & II & III & Average & SD & $\mathbf{I}$ & II & III & Average & SD \\
\hline Temperature $\left({ }^{\circ} \mathrm{C}\right)$ & 26.21 & 26 & 26 & 26.07 & 0.12 & 26.09 & 25 & 25 & 25.36 & 0.63 & 25.67 & 25 & 25 & 25.22 & 0.39 \\
\hline Light $(m)$ & 7.51 & 6.4 & 6.4 & 6.77 & 0.64 & 6 & 5.8 & 5.8 & 5.87 & 0.12 & 5.84 & 5.4 & 5.4 & 5.55 & 0.25 \\
\hline \multicolumn{16}{|l|}{ Chemical } \\
\hline & 7.92 & 7.6 & 8 & 7.84 & 0.21 & 8.02 & 8.3 & 7.4 & 7.91 & 0.46 & 8.04 & 8.2 & 7.2 & 7.81 & 0.54 \\
\hline Salinity ( \%o) & 33.5 & 32 & 32 & 32.5 & 0.87 & 25.95 & 31.2 & 28 & 28.38 & 2.65 & 24.91 & 31.3 & 29 & 28.40 & 3.24 \\
\hline DO (mg/l) & 6.76 & 6.9 & 6.45 & 6.70 & 0.23 & 7.23 & 7.42 & 7.5 & 7.38 & 0.14 & 7.52 & 7.34 & 7.4 & 7.42 & 0.09 \\
\hline Phosphate (mg/l) & 0.8 & 0.4 & 0.45 & 0.55 & 0.22 & 1.8 & 0.4 & 0.48 & 0.89 & 0.79 & 1.7 & $0 . .3$ & 0.5 & 1.10 & 0.85 \\
\hline \multirow[t]{2}{*}{ Nitrate $(\mathrm{mg} / \mathrm{l})$} & 0.2 & 0.32 & 0.37 & 0.30 & 0.09 & 0.82 & 0.65 & 0.65 & 0.71 & 0.10 & 0.79 & 0.7 & 0.68 & 0.72 & 0.06 \\
\hline & \multicolumn{15}{|c|}{ Locations } \\
\hline \multirow{2}{*}{ Parameters } & \multicolumn{5}{|c|}{ Awang } & \multicolumn{5}{|c|}{ Gerupuk } & \multicolumn{5}{|c|}{ Kuta } \\
\hline & $\mathbf{I}$ & II & III & Average & SD & I & II & III & Average & SD & I & II & III & Average & SD \\
\hline \multicolumn{16}{|l|}{ Physics } \\
\hline Temperature $\left({ }^{\circ} \mathrm{C}\right)$ & 25.87 & 25 & 25 & 25.29 & 0.50 & 26.02 & 26 & 26 & 26.01 & 0.01 & 26 & 26 & 26 & 26 & 0 \\
\hline Light (m) & 6.22 & 5.8 & 5.8 & 5.94 & 0.24 & 7.99 & 8.22 & 8.22 & 8.14 & 0.13 & 7.64 & 6.98 & 6.98 & 7.2 & 0.38 \\
\hline \multicolumn{16}{|l|}{ Chemical } \\
\hline $\mathrm{pH}$ & 7.92 & 8.24 & 8 & 8.05 & 0.17 & 7.6 & 7.87 & 7 & 7.49 & 0.45 & 7.72 & 7.8 & 8 & 7.84 & 0.14 \\
\hline Salinity (\%o) & 26.08 & 30.2 & 30.2 & 28.86 & 2.41 & 32.05 & 31.2 & 31.3 & 31.54 & 0.45 & 32.03 & 31.4 & 31.2 & 31.56 & 0.42 \\
\hline DO (mg/l) & 7.26 & 7.16 & 7.2 & 7.21 & 0.05 & 7.46 & 7.25 & 6.5 & 7.07 & 0.50 & 6.8 & 6.9 & 6.5 & 6.73 & 0.21 \\
\hline Phosphate (mg/l) & 1.93 & 0.3 & 0.4 & 0.88 & 0.91 & 1.72 & 0.3 & 0.1 & 0.71 & 0.88 & 1.76 & 0.2 & 0.1 & 0.69 & 0.93 \\
\hline Nitrate $(\mathrm{mg} / \mathrm{l})$ & 0.54 & 0.69 & 0.66 & 0.63 & 0.08 & 0.69 & 0.48 & 0.5 & 0.56 & 0.12 & 0.92 & 0.52 & 0.49 & 0.64 & 0.24 \\
\hline
\end{tabular}

Note: I $=2019$, II $=2020$, III $=2021$ 
Table 5. The total number and species composition of the sampled Bivalvia are associated with the six locations

\begin{tabular}{|c|c|c|c|c|}
\hline \multirow{2}{*}{$\begin{array}{l}\text { Family } \\
\text { Arcidae }\end{array}$} & Species & \multicolumn{3}{|c|}{ No. of No. of ind./ \% of ind } \\
\hline & Anadara granosa & 3 & 293 & 8.65 \\
\hline & Anadara antiquata & & 715 & 21.10 \\
\hline & Tegillarca addita & & 8 & 0.24 \\
\hline \multirow[t]{3}{*}{ Cardidae } & Fragum unedo & 3 & 4 & 0.12 \\
\hline & Modiolus philipinarum & & 52 & 1.53 \\
\hline & Trachhycardium flavum & & 61 & 1.80 \\
\hline Donacidae & Donax faba & 1 & 16 & 0.47 \\
\hline \multirow[t]{2}{*}{ Lucinidae } & Codakia tigerina & 2 & 56 & 1.65 \\
\hline & Lucinoma heroica & & 65 & 1.92 \\
\hline \multirow[t]{4}{*}{ Mactridae } & Mactrotoma ovalina & 4 & 8 & 0.24 \\
\hline & Mactrinula depressa & & 9 & 0.27 \\
\hline & Mactra grandis & & 31 & 0.91 \\
\hline & Mactra nitida & & 10 & 0.30 \\
\hline \multirow[t]{2}{*}{ Mytilidae } & Idas simpsoni & 2 & 9 & 0.27 \\
\hline & Perna viridis & & 567 & 16.73 \\
\hline \multirow[t]{2}{*}{ Pectinidae } & Chlamys luculenta & 2 & 4 & 0.12 \\
\hline & Marcia recens & & 27 & 0.80 \\
\hline \multirow[t]{2}{*}{ Pinnadae } & Atrina vexillum & 2 & 3 & 0.09 \\
\hline & Pinna muricata & & 48 & 1.42 \\
\hline Pteridae & Pinctada imbricata & 1 & 69 & 2.04 \\
\hline \multirow[t]{2}{*}{ Tellinidae } & Tellinella palatum & 2 & 11 & 0.32 \\
\hline & Tellinella staurella & & 18 & 0.53 \\
\hline \multirow[t]{25}{*}{ Veneroida } & Calista impar & 25 & 6 & 0.18 \\
\hline & Circe tumefacta & & 30 & 0.89 \\
\hline & Gafrarium tumidum & & 292 & 8.62 \\
\hline & Gafrarium dispar & & 32 & 0.94 \\
\hline & Gafrarium pectinatum & & 259 & 7.64 \\
\hline & Katelysia marmorata & & 4 & 0.12 \\
\hline & Lioconcha castrensis & & 9 & 0.27 \\
\hline & Lioconcha fastigiata & & 133 & 3.92 \\
\hline & Marcia hiantina & & 8 & 0.24 \\
\hline & Meretrix meretrix & & 10 & 0.30 \\
\hline & Paphia gallus & & 52 & 1.53 \\
\hline & Paphia undulata & & 34 & 1.00 \\
\hline & Pitar citrinus & & 21 & 0.62 \\
\hline & Pitar fulminatus & & 31 & 0.91 \\
\hline & Pitar simpsoni & & 11 & 0.32 \\
\hline & Pitar pellucidus & & 6 & 0.18 \\
\hline & Pitar subpellicidus & & 9 & 0.27 \\
\hline & Politita pesaureus & & 4 & 0.12 \\
\hline & Protapes gallus & & 6 & 0.18 \\
\hline & Samela australis & & 21 & 0.62 \\
\hline & Samela jecunda & & 101 & 2.98 \\
\hline & Tapes sulcaris & & 78 & 2.30 \\
\hline & Tapes belcheri & & 63 & 1.86 \\
\hline & Tapes literatus & & 79 & 2.33 \\
\hline & Tivela stefaninii & & 6 & 0.18 \\
\hline Total & & 47 & 3389 & 100 \\
\hline
\end{tabular}

The species richness or the number of species of bivalves from all study sites was much more than at other locations, such as Ela-Ela Sekotong Beach, West Lombok, with only six species (Zusron et al. 2015), or in the seagrass beds of Sungai Pulai, Peninsular Malaysia, with seven species as mentioned in (Daud 2008), and 18 species in the seagrass ecosystem of Kung Krabaen Bay, Chantaburi Province, Thailand (Satumanatpan et al. 2011), and on the Algarve coast of southern Portugal, with 25 species (Gaspar et al. 2002). The distribution and species richness of bivalves are limited to the local and a broader scale at the regional and global levels. The existence of bivalve species is critical to understanding their relationship with seagrass presence in tropical and subtropical coastal waters.

However, there can be different species richness between locations, even though the sites are close together. For example, the species richness of bivalves in the study area shows that Gili Kere has more species than in Lungak and Poton Bakau (Table 6). In addition, it can serve as information in the study of dominant factors that significantly determine the species richness of bivalves in a seagrass area, such as substrates and other environmental factors. The spatial distribution of bivalve species and their growth depends on the characteristics of the substrate, temperature, and water currents. These have a significant influence in determining the diversity of bivalve species (Bódis et al. 2011). Moreover, habitat conditions (substrate quality), the amount and species of available food, interactions between ecosystems in coastal waters, and oceanographic factors such as tides influence the distribution of bivalve species (Champion et al. 2020). Bivalve species are generally found on sandy and muddy substrate types but are often mainly sourced from coral rubble (Lukeneder 2008). Therefore, the species richness of bivalves at the six research sites can be a parameter for seagrass conservation.

Meanwhile, the species richness of Bivalves at the six research sites showed that Gili Kere had the highest number of species, and the lowest was in Lungkak (Table 6). Species with the highest distribution and distribution in all study sites were Anadara antiquata, Anadara granosa, and Gafrarium pectinatum, followed by the species Lioconcha fastigiata, Pinctada imbricata, and Tapes literatus, distributed in five study sites. Trachhycardium flavum was the only species distributed at four research sites. However, the highest number of Bivalvia species were distributed in two locations and reached $34.04 \%$, followed by the number of species at one place, which reached $29.78 \%$, and $19.14 \%$ at three sites (Table 5). Of the 14 species of bivalves found in one location, 12 species were in Gili Kere. The one species in Gerupuk was Calista impar, and one species in Kuta was Pitar citrinus (Table 5).

However, the highest individual species abundance value was of Perna viridis, only lying in Gili Kere. On the other hand, the species Anadara antiquata had the highest abundance in Lungkak, but was evenly distributed in the six study sites. Furthermore, the lowest abundance among Gili Kere species was for Atrina vexillum, Katelysia marmorata, Mactrotoma ovalina, and Tegillarca addita, while in Lungkak the lowest abundance was for Lioconcha fastigiata and Tegillarca addita. In Poton Mangrove, the most abundant species were Gafrarium tumidum, and the least abundant were Fragum unedo, Mactrotoma ovalina, Pinctada imbricata, and Pitar pellucidus. In contrast, in Awang the species with the highest abundance value was Anadara antiquata. The least abundant were Fragum unedo, Idas simpsoni, Mactra grandis, Tegillarca addita, and Pitar pellucidus. In Gerupuk the species with the highest abundance was Anadara antiquata, and the lowest abundance was of Pitar subpellicidus, Samela australis, and Samela jecunda. 
In Kuta, the species with the highest abundance was Anadara granosa, and those with the lowest abundance were Mactrinula depressa, Mactrotoma ovalina, and Tivela stefaninii.

The species composition of bivalves at each study site (Figure 3) shows the differences in the number of species between the seagrass bed locations. Gili Kere has the highest number of species $(57.45 \%)$, whereas Lungkak has the lowest number $(29.79 \%)$. The spatial species richness of bivalves is related to the seagrass environment, especially the substrate conditions at the six research sites (Table 3). The seagrass substrate on Gili Kere is mainly derived from coral rubble and a small amount of mud. Furthermore, three areas (Lungkak, Poton Bakau, and Awang) have a sandy silt substrate, and two locations (Gerupuk and Kuta) a silty, sandy seagrass substrate. Thus, the species richness of bivalves in seagrass areas could be limited by intertidal habitat (Nicholson and Lam 2005; Feng and Papeş 2017).

Furthermore, other environmental conditions were the limiting factors for the survival of the Bivalvia species at the study site (Table 4). Environmental viability values at all research sites are shown in Table 6. However, all environmental parameter values (i.e., temperature, brightness, $\mathrm{pH}$, salinity, DO, phosphate, and nitrate) were at the standard levels for marine life (KMNLH No 51 of 2014). Meanwhile, although the phosphate and nitrate values were higher at all study sites, they were still lower than the Redfield ratio, which is N:P (16:1). Environmental variables are a limiting factor, such as Anadara antiquata which requires a temperature range between $24{ }^{\circ} \mathrm{C}$ to $31^{\circ} \mathrm{C}$ (McPherson and Chapman 2000; Braby and Somero 2006). Currents and salinity can also affect bivalve species' distribution pattern and density (Schneider and Helmuth 2007; Harley et al. 2015). Another factor is the community's pattern of use, which contributes significantly to the preservation of bivalve species, such as at the study site. Further, the distribution of bivalve fauna is influenced by human activities and management strategies and other biological and environmental factors such as the type of substrate. Therefore, the spatial parameters of the distribution of Bivalvia species can be one of the considerations in seagrass conservation at the study site.

\section{Ecological index of fish species associated with seagrass in the six study sites}

The values of the ecological index, which includes the diversity index $\left(\mathrm{H}^{\prime}\right)$, evenness index $(\mathrm{E})(\mathrm{E})$, and abundance (Ki) of the bivalve species/year, and the average at the six research sites, are shown in Table 7 . The mean values for the $\mathrm{H}^{\prime}$ index and the standard deviation (SD) values at all study sites ranged from $1.94 \pm 0.20$ to $2.15 \pm 0.30$, with the highest $H^{\prime}$ index value in Awang and the lowest in Lungkak. Furthermore, the average value of the index $(\mathrm{E})$ and SD ranged from $0.62 \pm 0.07-0.73 \pm 0.07$, where the highest was in Lungkakand the lowest in Gili Kere. The average value of $\mathrm{Ki}$ and $\mathrm{SD}$ indices was $0.49 \pm 0.12-1.15 \pm$ 0.76 , the highest being in Lungkak and the lowest in Awang. The average value of the ecological index (Table 7) can explain the differences in the structure of the
Bivalvia community at each study site. The diversity index value describes the condition of the community structure, which is determined by the number of species and individual species of bivalves associated with seagrass.

Meanwhile, the species richness index value describes the number of different species related to seagrass in the six seagrass beds in the study location. The number of individuals/species does not determine the value of species richness. However, the abundance index value describes the individual abundance value of each Bivalvia species associated with seagrass at the six research sites (Table 6). In addition, spatially integrated Bivalvia species' ecological index values can be scientific information for developing sustainable landscape metrics, improving understanding of the area's ecological functions, and enabling management and monitoring of seagrass ecosystems' health (Barrell and Grant 2015). Therefore, the three parameters of the environmental index of Bivalvia species at the study site $\left(\mathrm{H}^{\prime}, \mathrm{E}\right.$, and $\left.\mathrm{Ki}\right)$ can enable the health assessment of seagrass ecosystems. Moreover, the ecological function of seagrass in the survival of Bivalvia species diversity at specific environmental index values $\left(\mathrm{H}^{\prime}, \mathrm{E}\right.$, and $\left.\mathrm{Ki}\right)$ is scientific evidence as a parameter of seagrass protection and conservation, such as at the study site.

The one-way ANOVA results show the ecological index values $\left(\mathrm{H}^{\prime}, \mathrm{E}\right.$, and $\left.\mathrm{Ki}\right)$ presented in Table 8 . The distribution of the results of the analysis is: F-count 5.12, F-table 2.14, and P-value 0.18, on the ecological index $\mathrm{H}^{\prime}$; F-count 5.12, F-table 3.08, and P-value 0.11 , on the environmental index E; and F. -count 5.12, F-table 2.96, and $\mathrm{P}$-value 0.12 , on the ecological index $\mathrm{Ki}$. The analysis results using the $\mathrm{F}$ test show from the comparison between the F-count and F-table values for each ecological index value ( $\mathrm{H}^{\prime}, \mathrm{E}$ and $\mathrm{Ki}$ ) that the $\mathrm{F}$-count value is higher than the F-table value. Therefore, it can be concluded that there are significant differences between the three parameters $\left(\mathrm{H}^{\prime}, \mathrm{E}\right.$, and $\left.\mathrm{Ki}\right)$ at each research location. Furthermore, based on the results of the dendrogram analysis (Figure 4), Lungak and Awang are in one group and are characterized by having the highest similarity of the three ecological index values, although geographically Lunkgak is closer to Poton Bakau and Gili Kere. Likewise, Gerupuk and Kuta, although geographically close together, are not in the same group.

On the other hand, Kuta has similarities with Gili Kere, although geographically the location does not differ. The level of similarity or grouping can explain that location proximity can lead to significant differences in species richness, the number of individuals/species, and species abundance of populations and communities of bivalves. Another explanation is that the distribution of bivalve species is not limited by geographic position. Still, the distribution of bivalve species is determined by the presence of seagrass in providing habitat to survive. Therefore, the variable of the ecological index values of Bivalvia species can be an essential aspect to be considered as a parameter of seagrass conservation, such as at the study site (Table 8). 
Table 6. The abundance of bivalve species found at the study site

\begin{tabular}{|c|c|c|c|c|c|c|c|c|}
\hline \multirow[b]{2}{*}{ Family } & \multirow[b]{2}{*}{ Species of bivalvia } & \multicolumn{6}{|c|}{ Abundance (Species/m²) } & \multirow{2}{*}{$\begin{array}{l}\text { Location with } \\
\text { Bivalvia species }\end{array}$} \\
\hline & & $\begin{array}{l}\text { Gili } \\
\text { Kere }\end{array}$ & Lungak & $\begin{array}{l}\text { Poton } \\
\text { Bakau }\end{array}$ & Awang & Gerupuk & Kuta & \\
\hline \multirow[t]{3}{*}{ Arcidae } & Anadara granosa & 0,03 & 0,32 & 0,09 & 0,31 & 0,37 & 0,60 & 6 \\
\hline & Anadara antiquata & 0,33 & 1,62 & 0,40 & 0,36 & 0,43 & 0,51 & 6 \\
\hline & Tegillarca addita & 0,01 & 0,03 & & 0,01 & & & 3 \\
\hline \multirow[t]{3}{*}{ Cardidae } & Fragum unedo & & & 0,01 & 0,01 & 0,02 & & 3 \\
\hline & Modiolus philipinarum & & 0,26 & & 0,04 & & 0,05 & 3 \\
\hline & Trachhycardium flavum & 0,04 & & & 0,08 & 0,11 & 0,11 & 4 \\
\hline Donacidae & Donax faba & & 0,12 & & 0,03 & & & 2 \\
\hline \multirow[t]{2}{*}{ Lucinidae } & Codakia tigerina & & & 0,15 & & 0,03 & & 2 \\
\hline & Lucinoma heroica & & & 0,15 & 0,03 & & 0,03 & 3 \\
\hline \multirow{4}{*}{ Mactridae } & Mactrotoma ovalina & 0,01 & & 0,01 & & & 0,01 & 3 \\
\hline & Mactrinula depressa & & 0,05 & & & & 0,01 & 2 \\
\hline & Mactra grandis & & 0,23 & & 0,01 & & & 2 \\
\hline & Mactra nitida & & & 0,28 & & 0,03 & & 2 \\
\hline \multirow[t]{2}{*}{ Mytilidae } & Idas simpsoni & & 0,04 & & 0,01 & & & 2 \\
\hline & Perna viridis & 1,80 & & & & & & 1 \\
\hline \multirow[t]{2}{*}{ Pectinidae } & Chlamys luculenta & 0,02 & & & & & & 1 \\
\hline & Marcia recens & 0,06 & & & & & & 1 \\
\hline \multirow[t]{2}{*}{ Pinnadae } & Atrina vexillum & 0,01 & & & & & & 1 \\
\hline & Pinna muricata & 0,09 & & & 0,03 & & 0,04 & 3 \\
\hline Pteridae & Pinctada imbricata & 0,03 & & 0,01 & 0,05 & 0,03 & 0,11 & 5 \\
\hline \multirow[t]{2}{*}{ Tellinidae } & Tellinella palatum & & & & 0,03 & 0,04 & & 2 \\
\hline & Tellinella staurella & 0,03 & & & & & & 1 \\
\hline \multirow[t]{25}{*}{ Veneroidae } & Calista impar & & & & & 0,04 & & 1 \\
\hline & Circe tumefacta & 0,04 & & & & & & 1 \\
\hline & Gafrarium tumidum & & 0,15 & 0,81 & & & & 2 \\
\hline & Gafrarium dispar & 0,05 & & & & & & 1 \\
\hline & Gafrarium pectinatum & 0,12 & 0,26 & 0,20 & 0,16 & 0,29 & 0,15 & 6 \\
\hline & Katelysia marmorata & 0,01 & & & & & & 1 \\
\hline & Lioconcha castrensis & 0,03 & & & & & & 1 \\
\hline & Lioconcha fastigiata & 0,09 & 0,03 & 0,12 & 0,11 & & 0,17 & 5 \\
\hline & Marcia hiantina & & & 0,02 & & & 0,05 & 2 \\
\hline & Meretrix meretrix & & 0,05 & & 0,02 & & & 2 \\
\hline & Paphia gallus & 0,08 & & & 0,05 & & 0,11 & 3 \\
\hline & Paphia undulata & 0,07 & & & & 0,02 & & 2 \\
\hline & Pitar citrinus & & & & & & 0,14 & 1 \\
\hline & Pitar fulminatus & & & 0,09 & & & & 1 \\
\hline & Pitar simpsoni & 0,02 & & & & 0,02 & 0,04 & 3 \\
\hline & Pitar pellucidus & 0,02 & & 0,01 & 0,01 & & & 3 \\
\hline & Pitar subpellicidus & & & 0,02 & & 0,01 & & 2 \\
\hline & Politita pesaureus & 0,02 & & & & & & 1 \\
\hline & Protapes gallus & 0,02 & & & & & & 1 \\
\hline & Samela australis & & & 0,05 & & 0,01 & & 2 \\
\hline & Samela jecunda & 0,01 & & 0,28 & & 0,01 & & 2 \\
\hline & Tapes sulcaris & 0,03 & 0,30 & 0,01 & 0,05 & 0,11 & 0,03 & 6 \\
\hline & Tapes belcheri & 0,11 & & & & 0,03 & 0,08 & 2 \\
\hline & Tapes literatus & 0,11 & 0,32 & 0,01 & 0,08 & 0,05 & & 5 \\
\hline & Tivela stefaninii & 0,01 & & & & & 0,01 & 2 \\
\hline \multicolumn{2}{|c|}{ Number of spesies } & 27 & 14 & 19 & 20 & 18 & 18 & \\
\hline \multicolumn{2}{|c|}{ Average abundance of bivalve $/ \mathrm{m}^{2}$} & 0,07 & 0,08 & 0,06 & 0,03 & 0,04 & 0,05 & \\
\hline
\end{tabular}

\section{Correlation of environmental factors with bivalves}

The results also show that three study locations had sandy mud, muddy sand, sand, and rocky sand substrate. The majority of mollusks prefer to live on a sandy mud substrate. Bivalves tend to choose sandy mud substrate, as the sand is easy to move/mobilize in, whereas mud substrate tends to have less oxygen content; therefore, the organisms living in it must adapt accordingly. At Gili Kere, the dominant type of substrate is sand from dead coral debris. In Lungkak, Poton Bakau, and Awang mud is more prevalent in the seagrass beds, with the mud originating from the river.

In the seagrass beds of Gerupuk and Kuta sand is more prevalent, with fine sand being deposited from run-offs. 
Since this is a source of seagrass's primary substrate, it can be an instrument in assessing the condition of seagrass, the pattern of seagrass distribution, and bivalves in these habitats. Furthermore, the species richness of bivalves associated with seagrass can provide information about the ecological warfare of seagrasses in providing habitat for the growth and development of bivalve communities.

The Pearson correlation value has a range $(\mathrm{r}=0-1)$, and the results of the correlation analysis of environmental variables with ecological index variables are between 0.028 - 0.875. The correlation values between environmental variables (Table 9) can help explain that environmental factors have a relationship with the diversity of bivalved species associated with seagrass, such as at the study site. However, the environmental conditions of all parameters are still at the standard allowed for marine life, including bivalve (KMNLH No. 51 of 2014), although the parameters from the investigators' results show differences in significance values of the ecological parameters of Bivalvia species (i.e., diversity, evenness, and abundance), as in Table 9. The index of evenness has a significant correlation of four parameters: nitrate $(\mathrm{r}=0.875)$, salinity $(0.552)$, DO $(\mathrm{r}=0.539)$, and phosphate $(\mathrm{r}=0.509)$. However, the two ecological indices, namely the diversity and abundance indices, show that the value obtained is $r<0.5$, revealing no significant correlation.

Table 8. The one-way ANOVA analysis of the ecological indices for seagrass-associated Bivalvia at the six study locations

\begin{tabular}{llccc}
\hline $\begin{array}{c}\text { One-way } \\
\text { Anova }\end{array}$ & $\begin{array}{c}\text { Source of } \\
\text { variation }\end{array}$ & $\begin{array}{c}\text { Diversity } \\
\text { index }\left(\mathbf{H}^{\prime}\right)\end{array}$ & $\begin{array}{c}\text { Evenness } \\
\text { index }(\mathbf{E})\end{array}$ & $\begin{array}{c}\text { Abundance } \\
(\mathbf{K i})\end{array}$ \\
\hline SS & Between Groups & 127.61 & 183.29 & 176.29 \\
& Within Groups & 536.26 & 536.24 & 536.55 \\
Df & Between Groups & 1 & 1 & 1 \\
& Within Groups & 9 & 9 & 9 \\
MS & Between Groups & 127.62 & 183.29 & 176.29 \\
& Within Groups & 59.58 & 59.58 & 59.62 \\
F-crit & & 5.12 & 5.12 & 5.12 \\
F-table & & 2.14 & 3.08 & 2.96 \\
P-value & & 0.18 & 0.11 & 0.12 \\
\hline
\end{tabular}

Table 7. Ecological index values for seagrass-associated Bivalvia species by year at the six study locations

\begin{tabular}{|c|c|c|c|c|c|c|}
\hline \multirow{2}{*}{ Location } & \multirow{2}{*}{ Index } & \multicolumn{3}{|c|}{ Year } & \multirow{2}{*}{ Mean } & \multirow{2}{*}{ \pm SD } \\
\hline & & 1 & 2 & 3 & & \\
\hline \multirow{4}{*}{ Gili Kere } & Species Diversity Index (H) & 1.93 & 2.3 & 1.91 & 2.05 & \pm 0.22 \\
\hline & Evenness Index (E) & 0.59 & 0.7 & 0.58 & 0.62 & \pm 0.07 \\
\hline & Abundance $(\mathrm{Ki})$ & 1.28 & 1.65 & 0.85 & 1.26 & \pm 0.40 \\
\hline & Species Diversity Index $(\mathrm{H})$ & 2.04 & 1.71 & 2.06 & 1.94 & \pm 0.20 \\
\hline \multirow[t]{3}{*}{ Lungkak } & Evenness Index (E) & 0.77 & 0.65 & 0.78 & 0.73 & \pm 0.07 \\
\hline & Abundance (Ki) & 0.86 & 2.26 & 0.73 & 1.28 & \pm 0.85 \\
\hline & Species Diversity Index $(\mathrm{H})$ & 1.79 & 2.01 & 2.42 & 2.07 & \pm 0.32 \\
\hline \multirow{3}{*}{ Poton Bakau } & Evenness Index (E) & 0.61 & 0.68 & 0.82 & 0.70 & \pm 0.11 \\
\hline & Abundance (Ki) & 0.55 & 2.03 & 0.2 & 0.93 & \pm 0.97 \\
\hline & Species Diversity Index $(\mathrm{H})$ & 2.36 & 1.81 & 2.27 & 2.15 & \pm 0.30 \\
\hline \multirow[t]{3}{*}{ Awang } & Evenness Index (E) & 0.79 & 0.6 & 0.76 & 0.72 & \pm 0.10 \\
\hline & Abundance (Ki) & 0.62 & 0.42 & 0.42 & 0.49 & \pm 0.12 \\
\hline & Species Diversity Index $(\mathrm{H})$ & 2.17 & 1.79 & 2.28 & 2.08 & \pm 0.26 \\
\hline \multirow[t]{3}{*}{ Gerupuk } & Evenness Index (E) & 0.75 & 0.62 & 0.79 & 0.72 & \pm 0.09 \\
\hline & Abundance (Ki) & 0.59 & 0.6 & 0.46 & 0.55 & \pm 0.08 \\
\hline & Species Diversity Index $(\mathrm{H})$ & 2.3 & 1.71 & 2.22 & 2.08 & \pm 0.32 \\
\hline \multirow[t]{2}{*}{ Kuta } & Evenness Index (E) & 0.8 & 0.59 & 0.77 & 0.72 & \pm 0.11 \\
\hline & Abundance (Ki) & 1.12 & 0.63 & 0.49 & 0.75 & \pm 0.33 \\
\hline
\end{tabular}

Table 9. Correlation of environmental parameters with ecological indices

\begin{tabular}{|c|c|c|c|c|c|c|c|c|c|c|}
\hline & Diversity & Evenness & Abundance & Temp. & Salinity & pH & Light & DO & Phosfat & Nitrat \\
\hline Diversity & 1 & & & & & & & & & \\
\hline Evenness & 0.015 & 1 & & & & & & & & \\
\hline Abundance & 0.743 & 0.524 & 1 & & & & & & & \\
\hline Temperature & 0.058 & 0.423 & 0.143 & 1 & & & & & & \\
\hline Salinity & 0.174 & 0.552 & 0.127 & 0.981 & 1 & & & & & \\
\hline $\mathrm{pH}$ & 0.053 & 0.014 & 0.287 & 0.554 & 0.479 & 1 & & & & \\
\hline Light & 0.175 & 0.028 & 0.465 & 0.870 & 0.807 & 0.770 & 1 & & & \\
\hline Do & 0.227 & 0.539 & 0.112 & 0.890 & 0.927 & 0.146 & 0.619 & 1 & & \\
\hline Phosfat & 0.032 & 0.509 & 0.038 & 0.915 & 0.921 & 0.257 & 0.716 & .904 & 1 & \\
\hline Nitrat & 0.117 & 0.875 & 0.298 & 0.699 & 0.794 & 0.166 & 0.414 & 0.735 & 0.817 & 1 \\
\hline
\end{tabular}




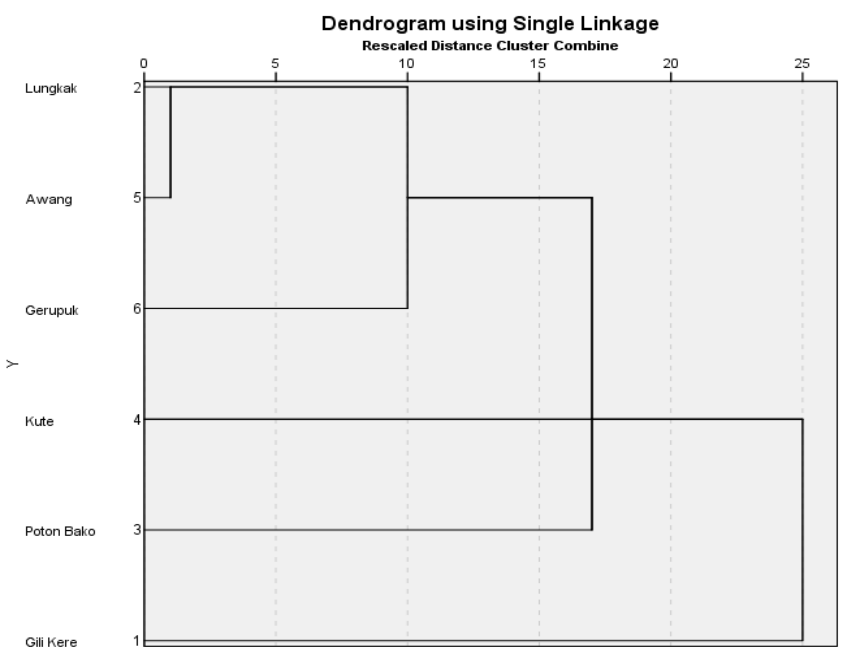

Figure 4. Cluster analysis of the Euclidean distance between seagrass-associated Bivalvia at the six study locations

It can be explained that the values of diversity and abundance of species are determined by other factors, such as the substrate. Nevertheless, Seo et al. (2013) explained that environmental parameters such as phosphate, salinity, nitrate, temperature, and organic matter are essential factors supporting the bivalve species' diversity to survive. In addition, a factor that has a significant contribution to the survival of the variety of bivalve species is the presence of seagrass, which can help create a suitable habitat for the growth and development of bivalve species (Syukur et al. 2021a). Therefore, the presence of bivalve species diversity in seagrass, such as in the study site, can be scientific information and can be considered as a parameter of local scale seagrass conservation, such as at the study site.

In conclusion, the species composition of Bivalves at the six research sites consisted of 11 families and 47 species. The location with the highest number of species was Gili Kere, and the lowest was Lungkak. Meanwhile, the family with the highest number of species was the Veneroidae family, including 25 species. In addition, the two families with the lowest number of species were the Donacidae and Pieridae families. Both families consist of only one species. Another parameter is the value of the ecological index (H', E, and $\mathrm{Ki}$ ), which can describe the richness of the Bivalvia community at each seagrass bed in the study location. Meanwhile, it was found that there was a significant difference in species richness of Bivalves from the six study sites. One of the limiting factors that caused differences in species richness from the six research sites was the suitability of substrate conditions. Therefore, ecological variables and environmental conditions are the main parameters for seagrass conservation, such as at the study site.

\section{ACKNOWLEDGEMENTS}

The authors are thankful to the Directorate General of Strengthening Research and Development. Directorate of
Research and Community Service, Ministry of Research, Technology and Higher Education of Indonesia for providing the funding for carrying out this study, based on decree number: 25/E1/ KPT2020, and agreement/contract number: 1734 / UN18.L1 / PP / 2021. All authors conducted all experiments, participated in data analysis and preparation of the manuscript.

\section{REFERENCES}

Abbott RT. 1985. Seashells of the World. Western Publishing Company Inc, New York, USA

Altamirano JP, Recente CP, Rodriguez Jr JC. 2017. Substrate preference for burying and feeding of sandfish Holothuria scabra juveniles. Fish Res 186: 514-523. DOI: 10.1016/j.fishres.2016.08.011.

Barrell J, Grant J. 2015. High-resolution, low-altitude aerial photography in physical geography: A case study characterizing eelgrass (Zostera marina L.) and blue mussel (Mytilus edulis L.) landscape mosaic structure. Prog Phys Geogr 39 (4): 440-459. DOI: $10.1177 / 0309133315578943$.

Bateman, DC, Bishop MJ. 2017. The environmental context and traits of habitat-forming bivalves influence the magnitude of their ecosystem engineering. Mar Ecol Prog Ser 563: 95-110. DOI: 10.3354/meps11959.

Best MM, Kidwell SM. 2016. Bivalve taphonomy in tropical mixed siliciclastic-carbonate settings. II. Effect of bivalve life habits and shell types. Paleobiology 26 (1): 103-115. DOI: 10.1666/00948373(2000)026<0080:BTITMS>2.0.CO;2

Bódis E, Nosek J, Oertel N, Tóth B, Hornung E, Sousa R. 2011. Spatial distribution of bivalves in relation to environmental conditions (middle Danube catchment, Hungary). Commun Ecol 12 (2): 210219. DOI: 10.1556/comec.12.2011.2.9.

Boudouresque CF, Bernard G, Pergent G, Shili A, Verlaque M. 2009. Regression of Mediterranean seagrasses caused by natural processes and anthropogenic disturbances and stress: A critical review. Botanica Marina 52 (5): 395-418: DOI: 10.1515/BOT.2009.057.

Braby, CE, Somero, GN. 2006. Following the heart: Temperature and salinity effects on heart rate in native and invasive species of blue mussels (genus Mytilus). J Exp Biol 209 (13), 2554-2566. DOI: $10.1242 /$ jeb.02259.

Chadwick MA, Dobberfuhl DR, Benke AC, Huryn AD, Suberkropp K, Thiele JE. 2006. Urbanization affects stream ecosystem function by altering hydrology, chemistry, and biotic richness. Ecol Appl 16 (5): 1796-1807. $\quad$ DOI: $10.1890 / 1051$ 0761(2006)016[1796:UASEFB]2.0.CO;2.

Champion C, Hobday AJ, Pecl GT, Tracey SR. 2020. Oceanographic habitat suitability is positively correlated with the body condition of a coastal - pelagic fish. Fish Oceanogr 29 (1): 100-110. DOI: 10.1111/fog. 12457 .

Chin DW, de Fouw J, van der Heide T, Cahill B, Katcher K, Paul VJ, Campbell JE, Peterson BJ. 2020. Facilitation of a tropical seagrass by a chemosymbiotic bivalve increases with environmental stress. J Ecol 109 (3): 7-22. DOI: 10.1111/1365-2745.13462.

Daud SK. 2008. Biodiversity and distribution of pen shells (Bivalvia: Pinnidae) from the seagrass beds of Sungai Pulai, Peninsular Malaysia. Res J Fish Hydrobiol 3 (2): 54-62.

de Souza AAM, Kloas W, Zarfl C, Hempel S, Rillig MC. 2018. Microplastics as an emerging threat to terrestrial ecosystems. Glob Change Biol 24 (4): 1405-1416. DOI: $10.1111 / \mathrm{gcb} .14020$.

Deutsch L, Troell M, Limburg K, Huitric M. 2011. Global trade of fisheries products: Implications for marine ecosystems and their services. In: Köllner T (eds.). Ecosystem Services and Global Trade of Natural Resources: Ecology, Economics and Policies. Routledge, London, UK.

Duniway MC, Bestelmeyer BT, Tugel A. 2010. Soil processes and properties that distinguish ecological sites and states. Rangelands 32 (6): 9-15. DOI: 10.2111/RANGELANDS-D-10-00090.1.

Ellenberg D, Mueller-Dombois D. 1974. Aims and Methods of Vegetation Ecology. Wiley and Sons, New York, USA. DOI: 10.2307/213332.

Feng X, Papeş M. 2017. Physiological limits in an ecological niche modeling framework: A case study of water temperature and salinity 
constraints of freshwater bivalves invasive in the USA. Ecol Model 346: 48-57.

Gagnon K, Rinde E, Bengil EG et al. 2020. Facilitating foundation species: The potential for plant-bivalve interactions to improve habitat restoration success. J Appl Ecol 57: 1161-1179. DOI: 10.1111/1365-2664.13605.

Gaspar MB, Santos MN, Vasconcelos P, Monteiro CC. 2002. Shell morphometric relationships of the most common bivalve species (Mollusca: Bivalvia) of the Algarve Coast (Southern Portugal). Hydrobiologia 477 (1-3): 73-80.

Harley JF, Carvalho L, Dudley B, Heal KV, Rees RM, Skiba U. 2015 Spatial and seasonal fluxes of the greenhouse gases $\mathrm{N}_{2} \mathrm{O}, \mathrm{CO}_{2}$ and $\mathrm{CH}_{4}$ in a UK macrotidal estuary. Coast Shelf Sci 153: 62-73. DOI: 10.1016/j.ecss.2014.12.004.

Hosack GR, Dumbauld BR, Ruesink JL, Armstrong DA. 2006. Habitat associations of estuarine species: Comparisons of intertidal mudflat, seagrass (Zostera marina), and oyster (Crassostrea gigas) habitats. Estuaries Coast 29 (6): 1150-1160. DOI: 10.1007/BF02781816.

Idrus AA, Syukur A, Zulkifli L. 2019. The diversity of fauna in mangrove community: Success replanting of mangroves species in South Coastal East Lombok, Indonesia. J Phys Conf Ser 1402 (3): 1-7. DOI: 10.1088/1742-6596/1402/3/033042.

Idrus AA, Syukur A, Zulkifli L. 2021. The evidence of Rhizophora as a potential species to improve mangrove recovery on the Southern Coast of East Lombok, Indonesia. ASM Sci J 14 (2): 57-54.

KMNLH. 2014. Baku Mutu Air Laut. Keputusan Menteri Negara Lingkungan Hidup No. 51, Jakarta. [Indonesian]

Kiswara W, Winardi L. 1994. Keanekaragaman dan sebaran lamun di Teluk Kuta dan Teluk Gerupuk, Lombok Selatan. J Teknologi Kelautan Nasional 3 (1): 23-36. [Indonesian]

Lebreton B, Richard P, Galois R et al. 2012. Food sources used by sediment meiofauna in an intertidal Zostera noltii seagrass bed: A seasonal stable isotope study. Mar Biol 159 (7): 1537-1550. DOI: 10.1007/s00227-012-1940-7.

Lee SW, Park SY, Kim Y et al. 2016. Effect of sulfidation and dissolved organic matters on toxicity of silver nanoparticles in sediment dwelling organism, Chironomus riparius. Sci Total Environ 553: 565573. DOI: 10.1016/j.scitotenv.2016.02.064.

Liu S, Jiang Z, Zhang J, Wu Y, Huang X, Macreadie P. 2017. Sediment microbes mediate the impact of nutrient loading on blue carbon sequestration by mixed seagrass meadows. Sci Total Environ 599: 1479-1484. DOI: 10.1016/j.scitotenv.2017.05.129.

Lu Y, Yuan J, Lu X et al. 2018. Major threats of pollution and climate change to global coastal ecosystems and enhanced management for sustainability. Environ Pollut 239: 670-680. DOI 10.1016/j.envpol.2018.04.016.

Lukeneder A. 2008. The ecological significance of solitary coral and bivalve epibionts on Lower Cretaceous (Valangianian - Aptian) ammonoids from the Italian Dolomites. Acta Geologica Polonica: 58 (4): 425-436.

Lukwambe B, Nicholaus R, Zhao L, Yang W, Zhu J, Zheng Z. 2020. Microbial community and interspecies interaction during grazing of ark shell bivalve (Scapharca subcrenata) in a full-scale bioremediation system of mariculture effluents. Mar Environ Res 158: 104956. DOI: 10.1016/j.marenvres.2020.104956

McPherson CA, Chapman, PM. 2000. Copper effects on potential sediment test organisms: The importance of appropriate sensitivity Marine Pollut Bull 40 (8): 656-665. DOI: 10.1016/S0025326X(00)00043-6.

Nicholson S, Lam MCC. 2005. Pollution monitoring in Southeast Asia using biomarkers in the mytilid mussel Perna viridis (Mytilidae: Bivalvia). Environ Intl 31 (1): 121-132. DOI: 10.1016/j.envint.2004.05.007.

Nordlund LM, Gullström M. 2013. Biodiversity loss in seagrass meadows due to local invertebrate fisheries and harbor activities. Estuar Coast Shelf Sci 135: 231-240. DOI: 10.1016/j.ecss.2013.10.019.

Nordlund ML, Koch EW, Barbier EB, Creed JC. 2016. Seagrass ecosystem services and their variability across genera and geographical regions. PLoS ONE 11(10): e0163091. DOI: 10.1371/journal.pone.0163091.

Odum EP. 1998. Ecology Basics. Translated from Fundamental of Ecology by T. Samingan. Gadjah Mada University Press, Yogyakarta. [Indonesian]

Odum EP. 1993. Basics of Ecology Third Edition. Translated from Fundamental of Ecology by T. Samingan. Gadjah Mada University Press, Yogyakarta. [Indonesian]

Patty SI. 2013. Distribution of temperature, salinity, and dissolved oxygen in Kema Waters. North Sulawesi. Platax 1 (3): 148 - 157. DOI: $10.35800 /$ jip.1.3.2013.2580.

Pitcher CR, Doherty P, Arnold P, et al. 2007. Seabed Biodiversity on the Continental Shelf of the Great Barrier Reef World Heritage Area. AIMS/CSIRO/QM/QDPI CRC Reef Research Task Final Report, Australia.

Rahman FA, Qayim I, Wardiatno Y. 2018. Carbon storage variability in seagrass meadows of Marine Poton Bako, East Lombok, West Nusa Tenggara, Indonesia. Biodiversitas 19 (5): 1626-1631. DOI: 10.13057/biodiv/d190505

Santhanam R. 2018. Biology and Ecology of Edible Marine Bivalve Molluscs. Apple Academic Press, Florida, USA. DOI: 10.1201/9781315111537.

Satumanatpan S, Thummikkapong S, Kanongdate K. 2011. Biodiversity of benthic fauna in the seagrass ecosystem of Kung Krabaen Bay, Chantaburi Province, Thailand. Songklanakarin J Sci Technol 33 (3): 340-348.

Seo JY, Lee JS, Choi JW. 2013. Distribution patterns of opportunistic molluscan species in Korean waters. Korean J Environ Biol 31 (1): 19. DOI: 10.11626/KJEB.2013.31.1.001

Schneider KR, Helmuth B. 2007. Spatial variability in habitat temperature may drive patterns of selection between an invasive and native mussel species. Mar Ecol Prog Ser 339: 157-167. DOI: 10.3354/meps339157.

Sousa R, Gutiérrez JL, Aldridge DC. 2009. Non-indigenous invasive bivalves as ecosystem engineers. Biol Invasions 11 (10): 2367-2385. DOI: $10.1007 / \mathrm{s} 10530-009-9422-7$.

Syukur A, Al-Idrus A, Zulkifli L. 2020. Ecotourism development based on the diversity of echinoderms species in seagrass beds on the south coast of Lombok island, Indonesia. J Environ Sci Technol 13 (2): 5768. DOI: $10.3923 /$ jest.2020.57.68

Syukur A, Idrus AAI, Zulkifli L. 2021a. Seagrass-associated fish species' richness: Evidence to support conservation along the south coast of Lombok Island, Indonesia. Biodiversitas 22 (2): 988-998. DOI: 10.13057/biodiv/d220255.

Syukur A, Hidayati BN, Idrus A, Zulkifli L. 2021b. The suitability of seagrass ecological function for the survival of the bivalvia on the East Coast of Lombok, Indonesia. IOP Conf Ser Earth Environmental Sci 712 (1): 012033. DOI: 10.1088/1755-1315/712/1/012033.

Unsworth RK, Butterworth EG. 2021. Seagrass meadows provide a significant resource in support of avifauna. Diversity 13 (8): 1-10. DOI: $10.3390 / \mathrm{d} 13080363$.

van der Heide T, Govers LL, de Fouw J, Olff H, van der Geest M, van Katwijk MM, van Gils JA. 2012. A three-stage symbiosis forms the foundation of seagrass ecosystems. Science 336 (6087): 1432-1434. $10.1126 /$ science. 1219973

Van Houte-Howes KSS, Turner SJ, Pilditch CA. 2004. Spatial differences in macroinvertebrate communities in intertidal seagrass habitats and unvegetated sediment in three New Zealand estuaries. Estuaries 27 (6): 945-957. DOI: 10.1007/BF02803421.

Wainwright BJ, Zahn GL, Arlyza IS, Amend AS. 2018. Seagrassassociated fungal communities follow Wallace's line, but host genotype does not structure the fungal community. J Biogeogr 45 (4): 762-770. DOI: 10.1111/jbi.13168.

Zhang YS, Silliman BR. 2019. A facilitation cascade enhances local biodiversity in seagrass beds. Diversity 11 (3): 1-12. DOI: 10.3390/d11030030.

Zusron M, Wibowo CA, Langgeng A, Firdausi FM, Etfanti S. 2015. Biodiversity of mollusks at Ela-Ela Beach, Sekotong West Lombok Indonesia. KnE Life Sci 2 (1): 574-578. DOI: 10.18502/kls.v2i1.219. 